\title{
Supply Chain Management - A Three Dimensional Framework
}

\author{
Vishal Gupta \\ Jaypee Business School, JIIT University \\ A-10, Sector-62, Noida, India \\ Tel: 91-120-259-4306_E-mail:guptav@rediffmail.com \\ Prof. Naseem Abidi \\ Jaypee Business School, JIIT University \\ A-10, Sector-62, Noida, India \\ Tel: 91-120-259-4480Ｅ-mail:drabidi@yahoo.com \\ Dr. Asit Bandyopadhayay (Corresponding author) \\ Jaypee Business School, JIIT University \\ A-10, Sector-62, Noida, India \\ Tel: 91-120-259-4471Ｅ-mail:asitb.76@gmail.com
}

Received: July 11, 2013 Accepted: September 25, 2013 Published: October 1, 2013

doi:10.5296/jmr.v5i4.3986

URL: http://dx.doi.org/10.5296/jmr.v5i4.3986

\begin{abstract}
The concept of Supply Chain Management (SCM) embraced the concern for environmental degradation and social responsibility in business management. This inclusiveness of ideas to SCM is being deliberated by the researchers as Sustainable Supply Chain Management (SSCM). The research paper employs integrative literature review approach to review, assess critically, and synthesize representative literature on the topic in an integrated way to suggest a new perspective of a three-dimensional framework. The paper integrates the idea of sustainability in supply chain management and suggests a Supply Chain (SC), Management (M) and Sustainability (S) as three dimensions of SSCM and delineates its constituents and their inter-relationships. The three levels of sustainability dimensions such as innovation,
\end{abstract}




\section{Macrothink}

Journal of Management Research ISSN 1941-899X 2013, Vol. 5, No. 4

environment and social have similar hierarchical structure as operational, tactical and strategic levels of management. To make a SC sustainable, all SC actors have to ensure their performance on all the three levels of management and sustainability dimension. The framework is comprehensive and will help the practitioners to have a better conceptualization, design and plan for a sustainable supply chain.

Keywords: Supply chain, Management, Sustainability, Innovation, Environment, Social 


\section{Introduction}

The way the business is done at present has undergone radical transformation due to globalization and outsourcing, intense competition and changing markets, use of technology and information sharing, to address ever increasing expectations of consumers. The liberalization of economic policies across the globe and increased focus on environmental and social issues has made the business environment more dynamic and complex. The focus has shifted from a single organization to a network of organizations collaborating together to provide real-time solutions. Integration of business activities and collaboration with upstream and downstream partners has become an integral part of doing business. The realization of importance of integration and collaboration among the partners for efficient and economic utilization of resources leading to better profit margins among all partners; and customer service lead to the idea of Supply Chain Management (SCM). Organizations have realized that effective and efficient management of supply chains is essential for present and future survival (Olhager, Perssom, Parborg, \& Rosén, 2002). The importance of supply chain management has grown over a period of time and various planning models have been put into practice by organizations across the globe. In the competitive global environment, performance of an organization can no longer solely be determined by the decisions and actions that occur within a firm; rather it will depend on the execution of decisions and actions taken in its entire supply chain (Naslund \& Williamson, 2010).

However, the concept of SCM addressed the issues relating to efficiency and effectiveness of the entire chain of the business entities it has shown least concern to the environmental issues Now when protection of environment has become an important national and global concern, it is imperative on businesses also to take up the responsibility of making their supply chains environment friendly. Environmental problems associated with waste and emissions produced from various supply chain activities have forced organizations, facing competitive, regulatory and community pressures, to move towards greening their supply chains (Barve \& Muduli, 2011). This inclusiveness leads to the concept of Green Supply Chain Management (GrSCM), which integrates the ecological factors with supply chain management principles to address how an organization's supply chain processes may conserve the environment.

Meanwhile, the issues such as human rights, safety of the workers as well as of the society at large and concern for enhancing the quality of life began to appear centre stage in the global outlook, the business groups also have to address their responsibilities. The idea is being embraced by the researchers to suggest organizations having reporting on supply chain on triple parameters as economic, environment and social performance. The whole idea of integrating these three parameters is to develop a concept of Sustainable Supply Chain Management (SSCM), which reduces cost, protect environment and help to the society at large. A sustainable supply chain is a supply chain that is not only optimal for the focal firm, but is optimal relative to its environmental and societal impact. Research in SCM has examined issues such as environment safety, social welfare and their interrelationship with organization's economic responsibility (Carter \& Rogers, 2008). Existing frameworks for SSCM in literature are reviewed to propose three-dimensional framework. 


\section{Literature review}

The modern idea of a supply chain is attributed to the pioneering research conducted by Jay Forrester at the Massachusetts Institute of Technology (MIT) in the 1950s. Forrester (1961) in his industrial dynamics model (widely known as Forrester effect), suggested that five flows of any economic activity namely - money, orders, materials, personnel and equipment - are interrelated by an information network, which is now called a supply chain. In the early 1980s, the concepts of transportation, distribution and material management began to merge into a single, all- encompassing term: supply chain management. The term apparently first appeared in print in 1982, and is attributed to Keith Oliver, a consultant with Booz Allen Hamilton (Ayers, 2006).

Fox et al. (1993) defined supply chain as a set of activities which span enterprise functions from the ordering and receipt of raw materials through the manufacturing of products through the distribution and delivery to the customer. In order to operate efficiently, these functions must operate in an integrated manner. Providing rapid and quality responses to supply chain events requires the coordination of multiple functions across the enterprise. Supply chain management functions operate on three levels (Figure 1): strategic level, tactical level, and operational level (Fox, Chionglo, \& Barbuceanu, 1993). Each level is distinguished by the time horizon over which decisions are made, and the granularity of decisions during that period.

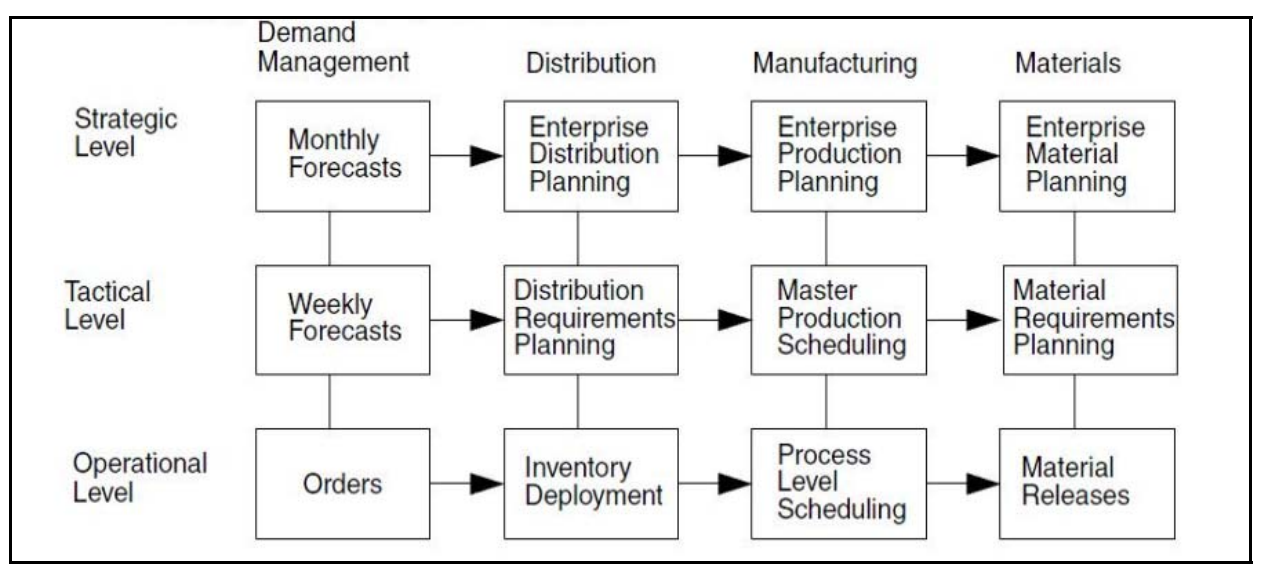

Figure 1. Supply chain management functions

Source: (Fox, Chionglo, \& Barbuceanu, 1993)

Mentzer et al., (2001) proposed a supply chain as a "set of three or more entities directly involved in the upstream and downstream flow of products, services, finances, and information from a source to the customer" with a clear emphasis on management of flows. While Fleischmann et al., (2002) divided the supply chain into four main stages or processes and described their purpose. Procurement involves the operations of providing the raw material and resources necessary for production. Production is the next process in the chain in which the raw materials are converted into intermediary and/or finished products. Thereafter, 
distribution includes the logistics to move the products either to companies for further processing the product or to distribution centres, and finally to point of sales. All demand planning issues including customer or market selection, forecasting, pricing strategy and order promising policies are part of the sales process.

Fleischmann and Meyr (2003) provided the framework that encompasses the operational, tactical and strategic analysis for decision making at short-term, mid-term and long-term levels respectively (Figure 2). The degree of detail increase and the planning horizon decreases by shifting from the long-term to the short-term.

Long-term planning decisions are called strategic decisions and create the prerequisites for the development of an enterprise and it's /supply chain. These decisions typically concern the design and structure of a supply chain and have long-term effects, which are noticeable over several years. Mid-term planning is within the scope of the strategic decisions and is an outline of the regular operations. It is also referred as tactical planning and the planning horizon ranges from 6 to 24 months. Short-term planning is the lowest planning level which specifies all activities and detailed instructions for direct execution and control. Therefore, short-term planning requires the highest degree of detail and accuracy at the operational level. The planning horizon at this level ranges from a few days to three months.

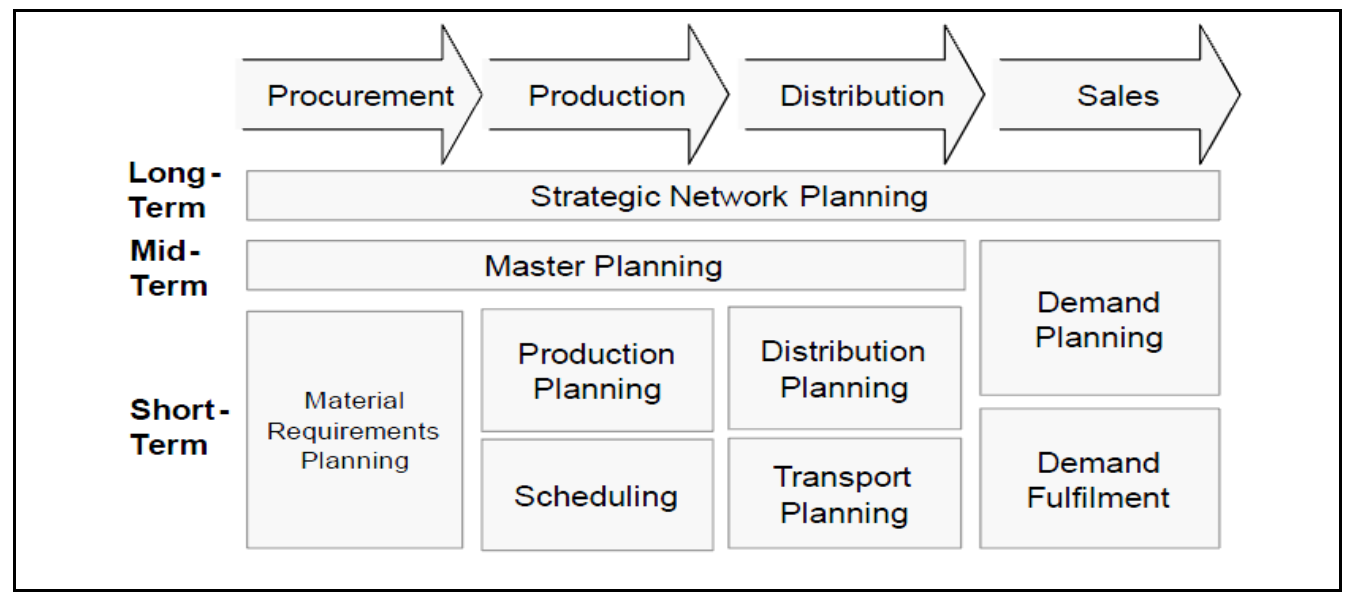

Figure 2. Supply Chain Planning Matrix

Source: (Fleischmann \& Meyr, Planning Hierarchy, Modeling and Advanced Planning Systems, 2003)

Strategic decisions in supply chains are made for the long term (usually a couple of years or more) and are expensive to alter. Strategic decisions expound the way for decisions regarding the management of supply chain operations for shorter horizons. This involves tactical decisions, which have a horizon of about three months to a year; and operations decisions, which have a horizon ranging from a day to a month (Singh \& Shah, 2001). While Chow et al. (2006) argued that the business executives and managers recognize that the ultimate success of any enterprise is no longer built around a firm's capability and capacity, but on a supply chain's capability and capacity. 


\subsection{Innovation in Supply Chain Management}

The importance and its widespread effect on innovation are always recognized by society and business. This can take place within processes, products, services, organizational structures, management strategies etc. Broadly it can be classified under continuous improvement or discontinuous and radical shifts in technology or ways of approaching a problem (Rogers, 1995) (Cooper, 1999) (Kahn, 2001). Changing business environment and technological advancements increased the level of competition and also the need for innovation for survival and growth. Innovation can be focused on cost improvements, process improvements, product or service line extensions, new uses/reuse, new markets and customers or new technologies. Christmann (2000) suggested that the organizations having capabilities for process innovation and implementation will be leaders in sustainability.

Realizing the importance of coordination and collaboration due to globalization, increased customer responsiveness, channel integration and advances in information and communication technologies (ICT), firms started planning, designing, innovating and implementing their supply chain. The key to successful supply chain management is coordination within an organization and between its suppliers and customers. Firms with the ability to better manage their supply chains should experience superior supply chain innovations (Modi, 2006). Collaboration in supply chains is important for innovation as partners realize the various benefits of innovation such as high quality, lower costs, more timely delivery, efficient operations and effective coordination of activities (Soosay, et al., 2008). Supply chain and logistics managers play a role in innovation in at least two ways, i.e., one by developing innovations in supply chain management processes that themselves help create a differential advantage for firms and ideally supply chains and two, by superior execution in support of product innovations developed by OEMs (original equipment manufacturers) (Flint, et al., 2008).

The degree of newness may be related to both technological innovations (new products or processes) and non-technological innovations (organizational innovation or market innovation) (Bigliardi \& Dormio, 2009). An intra-organizational innovation might be the application of new technologies for planning and forecasting, whereas an example of inter-organizational or market innovation might be the application of integrated product development in which suppliers and customers become part of the product development process (Santos \& Smith, 2008).

Storer and Hayland, 2009 proposed that like the firm, the supply chain also uses innovation to provide unique value adding solutions for the supply chain that provides a market competitive advantage. Employing a supply chain's innovation capacity indicates the willingness of groups of actors within the supply chain to take steps, or perform activities that ultimately produce output that improves or changes current activities to meet a market need or new trajectory (Storer \& Hyland, 2009). The introduction of new products and services, or entry into new markets, is likely to be more successful if accompanied by innovative supply chain designs, innovative supply chain management practices, and enabling technology (Jan Stentoft, et al., 2011). 
Recently much attention has been paid to innovation as a way for industry and policy makers to achieve more radical, systemic improvements in corporate environmental practices and performance. Many companies have started to use eco-innovation or similar terms to describe their contributions to sustainable development (Machiba, 2009). Eco-innovation represents innovation that results in a reduction of environmental impact, no matter whether that effect is intended or not. Eco-innovation is thus seen as an overarching concept which provides direction and vision for pursuing the overall societal changes needed to achieve sustainable development. (METI \& OECD, 2010). Innovation has long been seen as central to economic performance; it is increasingly recognized as a significant driver of social welfare.

\subsection{Green Supply Chain Management (GrSCM)}

The aim of supply chain management is to integrate the processes in a supply chain for efficient utilization of resources and reduction in costs, leading to shareholder's profit maximization. However, the broader concept of stakeholder's theory (Freeman, 1984) demands that a company's responsibility lies with stakeholders rather than shareholders. In this case, "stakeholders" refers to anyone who is influenced, either directly or indirectly, by the actions of the firm. Supply chain processes involve exploitation of natural resources as well as the human capital. Thus the stakeholders in a supply chain would include the society as well as the ecological environment.

With an increased focus on environment issues, the component "green" got involved to address the influence and relationships of supply chain management to the natural environment. Zhu and Sarkis (2004) took this idea further and argued that GrSCM practices are only about 'win-win relationships on environmental and economic performance'. Hervani et al. (2005) described the idea of GrSCM is to eliminate or minimize waste (energy, emissions, chemical/hazardous, and solid wastes) along supply chain. They identified a number of environmentally conscious practices throughout the supply chain ranging from green design (marketing and engineering), green procurement practices (e.g. certifying suppliers, purchasing environmentally sound materials/products), total quality environmental management (internal performance measurement, pollution prevention), environmentally friendly packaging and transportation, to the various product end-of-life practices such as reduction, reuse, remanufacturing \& recycling. In the scope of supply chain management, reverse logistics is used to manage the return flow of products. Reverse logistics is a process whereby a manufacturer accepts products from consumers for possible remanufacturing, recycling, reuse or disposal (Dowlatshahi, 2000). Reverse logistics includes not only the returns from the customers, but also handling the product at 'end-of-life'.

The GrSCM can be expressed as (Hervani, et al., 2005)

Green Supply Chain Management = Green Purchasing + Green Manufacturing/ Materials Management + Green Distribution/Marketing + Reverse Logistics.

Rao and Holt (2005) divided the environmental initiatives in a green supply chain in inbound logistics; production or the internal supply chain; outbound logistics; and reverse logistics; including and involving materials suppliers, service contractors, vendors, distributors and end users working together to reduce or eliminate adverse environmental impacts of their 
activities. Their analysis identified that greening the different phases of the supply chain leads to an integrated green supply chain, which ultimately leads to competitiveness and economic performance. Greening the inbound function involves the integration of suppliers into a green supply chain. Getting the suppliers make their operations green helps tremendously in cutting down production of waste at source. Similarly, greening of production results in the minimization of pollution, and reverse logistics processes help in re-use of materials and recycling initiatives. This leads to savings in raw materials, water and energy usage and thus leads to competitiveness and economic performance.

All stages of a product's life cycle influence a supply chain's environment burden, from resource extraction, to manufacturing, use and reuse, final recycling, or disposal (Zhu et al, 2007). The findings by Rao \& Holt (2005) show that organizations as well as environment gain with the implementation of green supply chain initiatives. Other studies (Srivastava \& Srivastava, 2006); (Srivastava, 2007); (Darnall, et al., 2008) also have shown that profitability and cost reduction are some of the main motivators for businesses to become 'green' in the supply chain. Therefore, GrSCM gained popularity with both academics and practitioners to aim in reducing waste and preserving the quality of product-life and the natural resources (Fortes, 2009). Now, when global warming and environmental exploitation have become issues at global level and countries have committed to control the situations at international forums, the concepts of SCM are being transformed to GrSCM, which means conducting business to meet human needs without rapidly depleting resources, degrading the environment, or compromising nature conservation efforts (Gupta, et al., 2013).

\subsection{Sustainable Supply Chain Management (SSCM)}

In the year 1981 Freer Spreckley argued that enterprises should measure and report on social, environmental and financial performance (Spreckley, 1981). The idea of integrating social and environmental factors to economic activity is termed as sustainability. One of the initial definitions of sustainability comes from the Brundtland Commission (World Commission on Environment and Development 1987), which defines sustainability as "development that meets the needs of the present without compromising the ability of future generations to meet their needs.” One of the early reference to sustainability is made by O'Connor (1994) who points out the question of "sustainability" is not primarily an ecological (or even economic) argument, but one of politics and ideology (O’Connor, 1994).

This concept of sustainability corresponds with the Triple Bottom Line (TBL) perspective given by Elkington (1998) which states that, at the intersection of social, environmental, and economic performance are activities that an organization can engage in which not only are beneficial from a social and environmental standpoint, but that also make economic sense and result in competitive advantage for the firm (Elkington, 1998). Dyllick and Hockerts (2002) conceived corporate sustainability as the business case (economic), the natural case (environmental), and the societal case (social). The triple bottom line has been identified as a tool to measure the organization's progress towards the end goal of being truly sustainable (Pagell \& Wu, 2009). The term sustainability, which increasingly refers to an integration of social, environmental, and economic responsibilities, has begun to appear in the literature of 
business disciplines such as management and operations. Carter and Rogers (2008) suggest that organizational sustainability, at a broader level, consists of three components: the natural environment, society, and economic performance. The concept of sustainability has been extended from the organization to the supply chain. SSCM must include the sustainability dimension parameters in whole framework of SCM. The first paper on sustainability in supply chain is attributed to New (1997) who argued that supply chain management in industrial society should explicitly consider ethical, political and economic implications. A supply chain's performance should be measured not just by profits, but also by the impact of the chain on ecological and social systems (Gladwin, et al., 1995); (Starik \& Rands, 1995); (Jennings \& Zandbergen, 1995).

Based on the TBL concepts of sustainability and a review of supply chain management literature, Carter and Rogers (2008) proposed their own model and defined SSCM as "the strategic, transparent integration and achievement of an organization's social, environmental, and economic goals in the systematic coordination of key inter-organizational business processes for improving the long-term economic performance of the individual company and its supply chains.” They conceptualize this definition in a model as shown in Figure 3 given below.

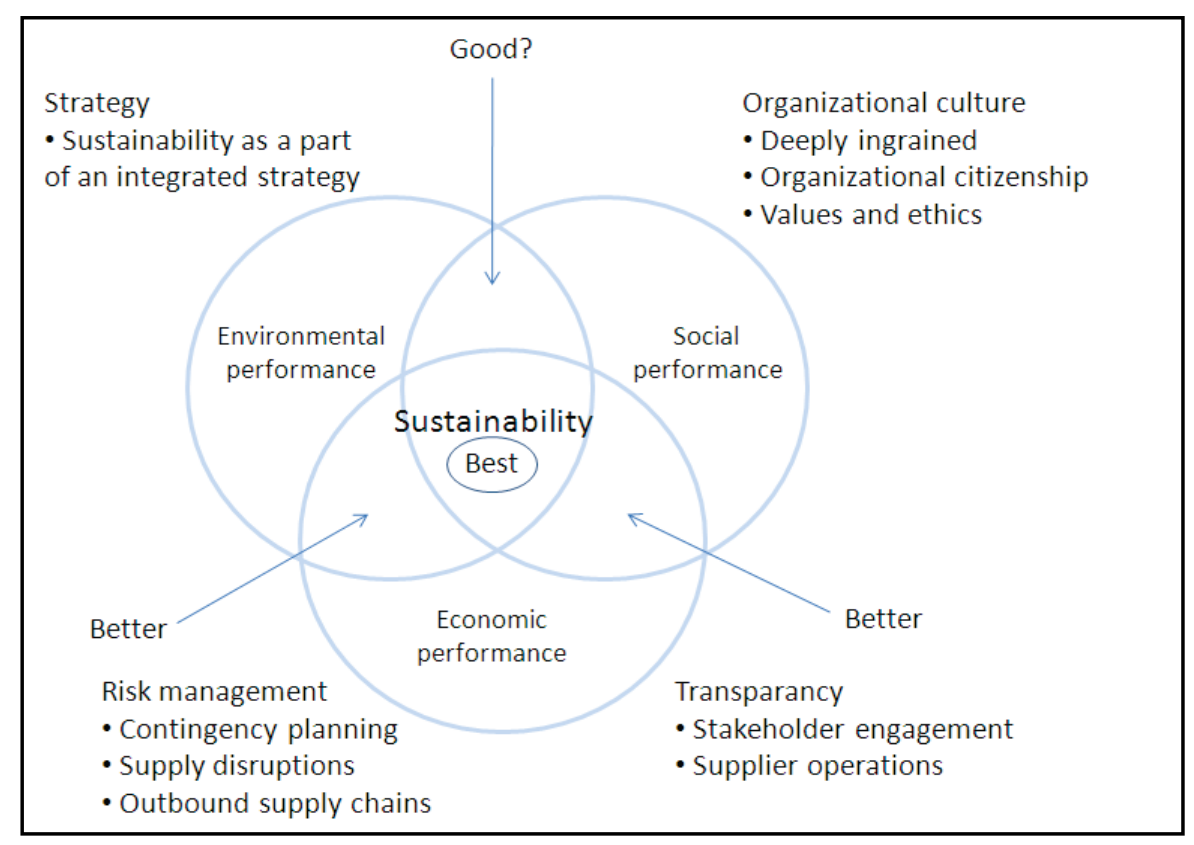

Figure 3. SSCM Model

Source: (Carter \& Rogers, 2008)

Highest level of economic performance will occur at the intersection of environmental, social, and economic performance as shown in Figure 3 above. Thus, firms which attempt to simultaneously maximize performance of all three dimensions of the triple bottom line will outperform organizations that attempt to only maximize economic performance, or 
companies that attempt to achieve high levels of social and environmental performance without explicit consideration of economic performance (Carter \& Rogers, 2008).

A sustainable supply chain is then one that performs well on both traditional measures of profit and loss as well as on the expanded conceptualization of performance that includes social and natural dimensions (Pagell \& Wu, 2009). They used the case studies of ten exemplar firms to build a coherent and testable model ( Figure 4) of management practices that supply chain managers will need to engage in to create a sustainable supply chain.

Pagell \& Wu, 2009 examined the chain in its entirety, by explicitly examining both the social and environmental outcomes of the supply chain activities. The case analysis identifies that the organizational capability to innovate and positive management orientation towards sustainability are a precursor to sustainable supply chain management. It also lineate the actions performed by managers of sustainable supply chains, viz. they collaborate with non-traditional members such as NGOs, regulators, competitors and members of the community; and they focus on sourcing side activities such as supplier certification, including social and environment criteria in supplier selection. Thus the organization's innovation capabilities and its alignment towards environmental, social and economic goals lead to an economically viable as well as sustainable supply chain.

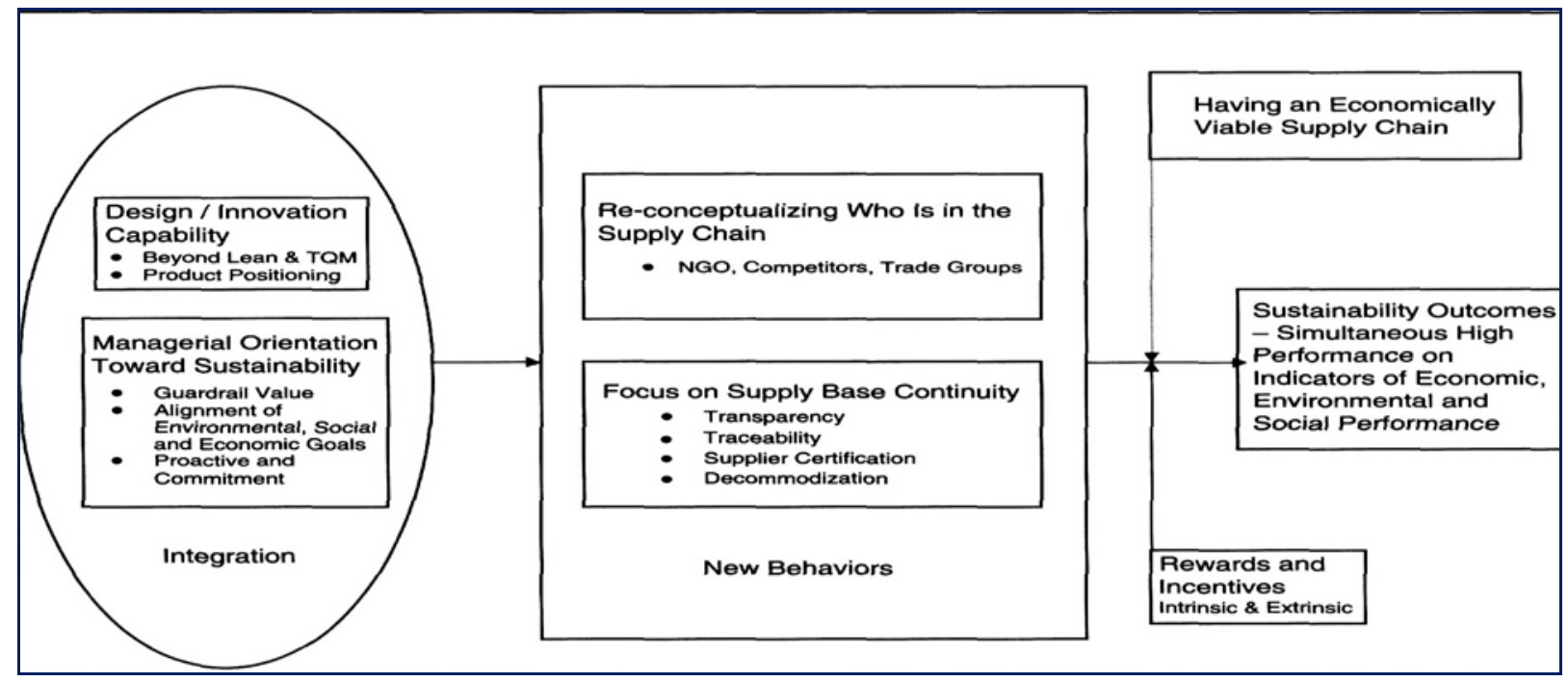

Figure 4. A Model for SSCM Practices

Source: (Pagell \& Wu, 2009)

Mann et al., (2010) identified the drivers that motivate firms to the move towards creating sustainable supply chains. Based on the extant literature review, they classified the drivers that motivate firms to implement sustainable SCM practices based on the 'balanced scorecard configuration' culled from the research of Kaplan and Norton (2007). Figure 5 below provides an overview of these drivers in relation to sustainable SCM. The classification of these drivers is done into financial, internal business process, customer, environment, legislation and social. For long-term sustainability, the balancing of these five classes of 
drivers, i.e., financial, internal business process, customer, environment, legislation and social is critical.

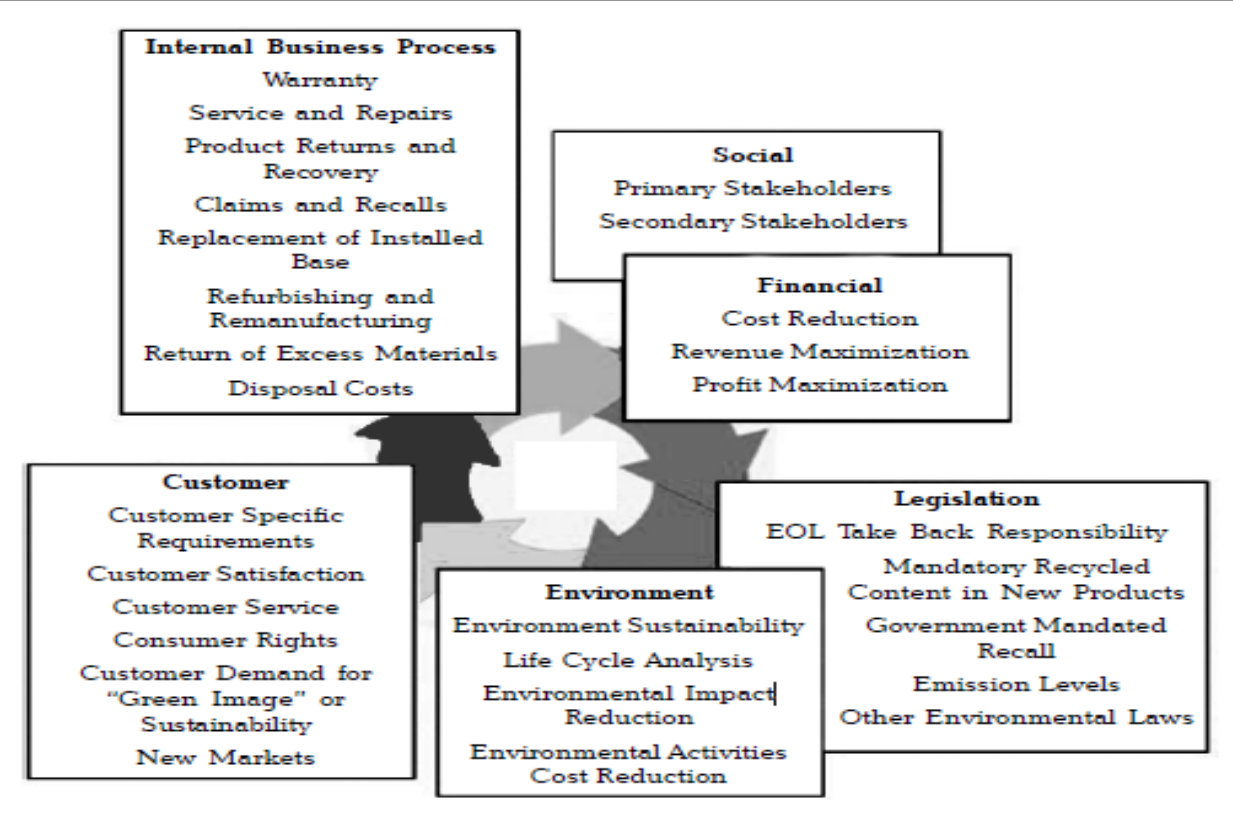

Figure 5. Drivers for Sustainable Supply Chains

Source: (Mann, Kumar, Kumar, \& Mann, 2010)

Combining definitions of SCM and sustainability, Seuring and Müller (2008) define SSCM as "the management of material, information and capital flows as well as cooperation among companies along the supply chain while taking goals from all three dimensions of sustainable development, i.e., economic, environmental and social, into account which are derived from customer and stakeholder requirements". As such, members in a sustainable supply chain have to fulfil environmental and social criteria but equally have to remain competitive by meeting customer demands and related economic criteria.

Ramudhin et al. (2010) adopted this definition and proposed a framework (Figure 6) that incorporates all three dimensions of sustainability: economic, social and environmental. Here supply chain economics is taken into consideration by minimizing the total logistic cost or maximizing the profit over the different supply chain activities (purchasing, production, warehousing, distribution, recycling, etc). Environmental sustainability means that permanent environmental damages should not be allowed and green house gases (GHGs) emissions regulations enforced. The social dimension includes such objective as to reduce noise, traffic congestion, and stress and improve the standard and quality of life of communities around the supply chain. 


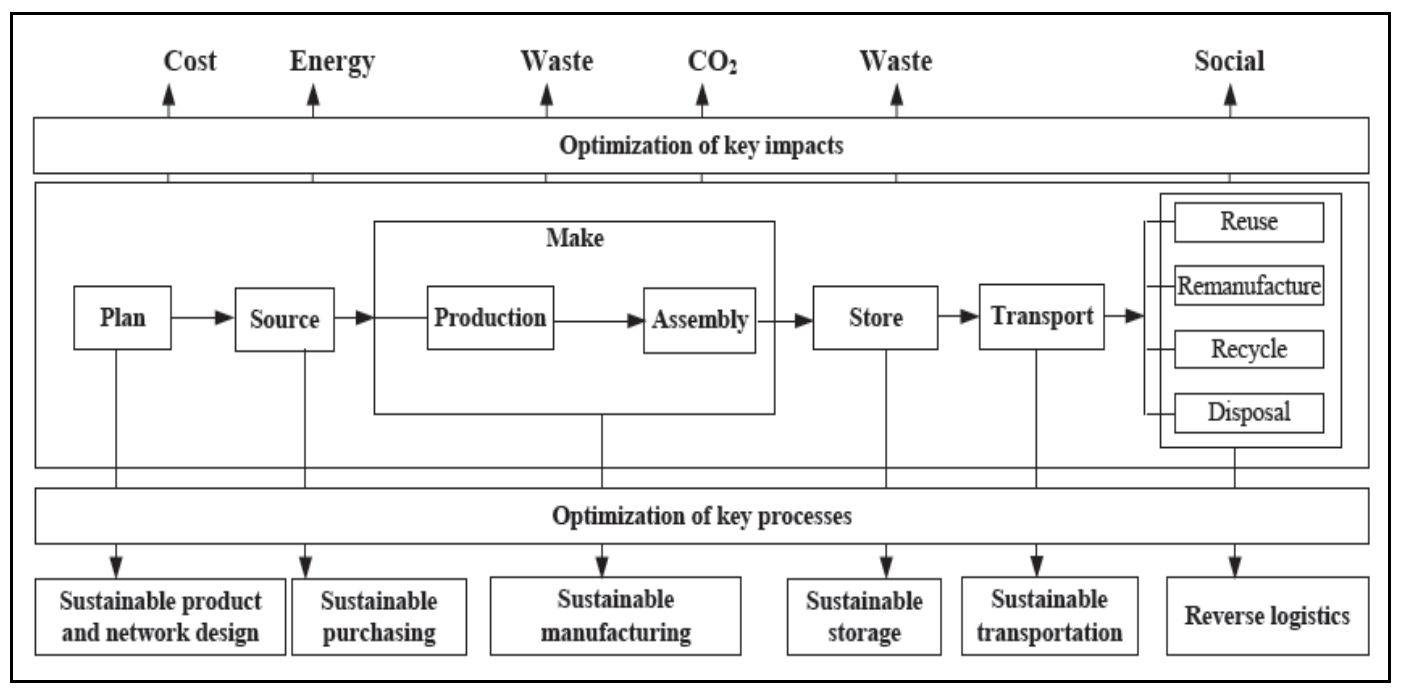

Figure 6. Sustainable Supply Chain Management

Source: (Ramudhin, Chaabane, \& Paquet, 2010)

Dey et al. (2011) integrated sustainability with the different processes in a supply chain. They showed a simplified supply chain broken down into the supply chain, value adding chain, distribution chain, and the reverse logistics chain (错误! 未找到引用源。). In this study, the supply chain refers to the operations involved in securing the materials that will make up the goods or services being produced from multiple suppliers as well as the transportation of those goods to the manufacturing facility. The value adding chain refers to the corporation, the management, and the operations involved in manufacturing the goods or services. The distribution chain refers to the operations involved in getting the finished goods to the consumers. Finally, 错误! 未找到引用源。 also includes the emerging idea of reverse logistics, shown as sustainable end of product life (Dey, et al., 2011). Over the last decade reverse logistics has become increasingly important as firms take responsibility for their products once the consumer has no more need for them (Meade, et al., 2007); (Prahinski \& Kocabasoglu, 2006). 


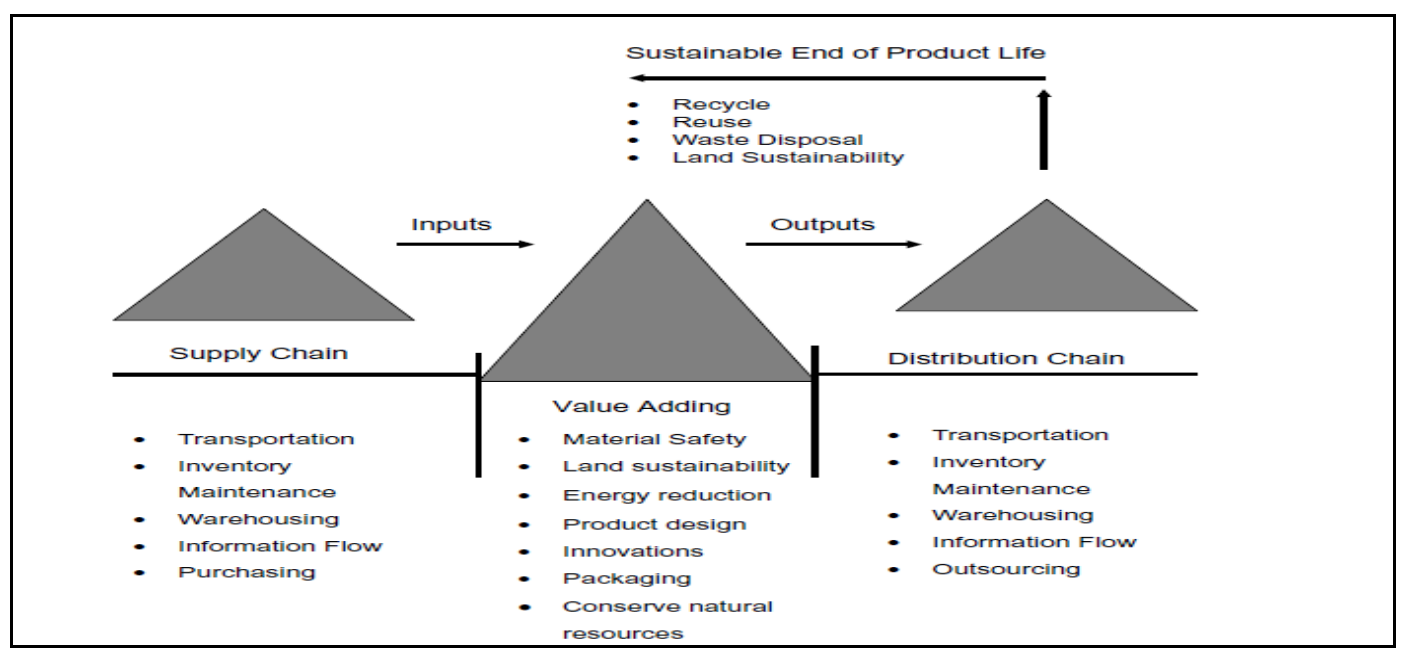

Figure 7. Sustainable Supply Chain Management

Source: (Dey, LaGuardia, \& Srinivasan, 2011)

Hassini et al. (2012) envisage a sustainable supply chain as wheels constituting of six spokes, representing the major relevant functions within the chain: sourcing, transformation, delivery, value proposition, customers, and recycling (Figure 8). They highlighted the role of green procurement, green design, reduction of use of toxic substances, use of green technology and choice of mode of transportation resulting in lower green house gas (GHG) emissions, renewable sources of energy, ethical labor practices, fair trade practices, reuse, recycle and return of products in making the supply chain sustainable (Hassini, Surti, \& Searcy, 2012).

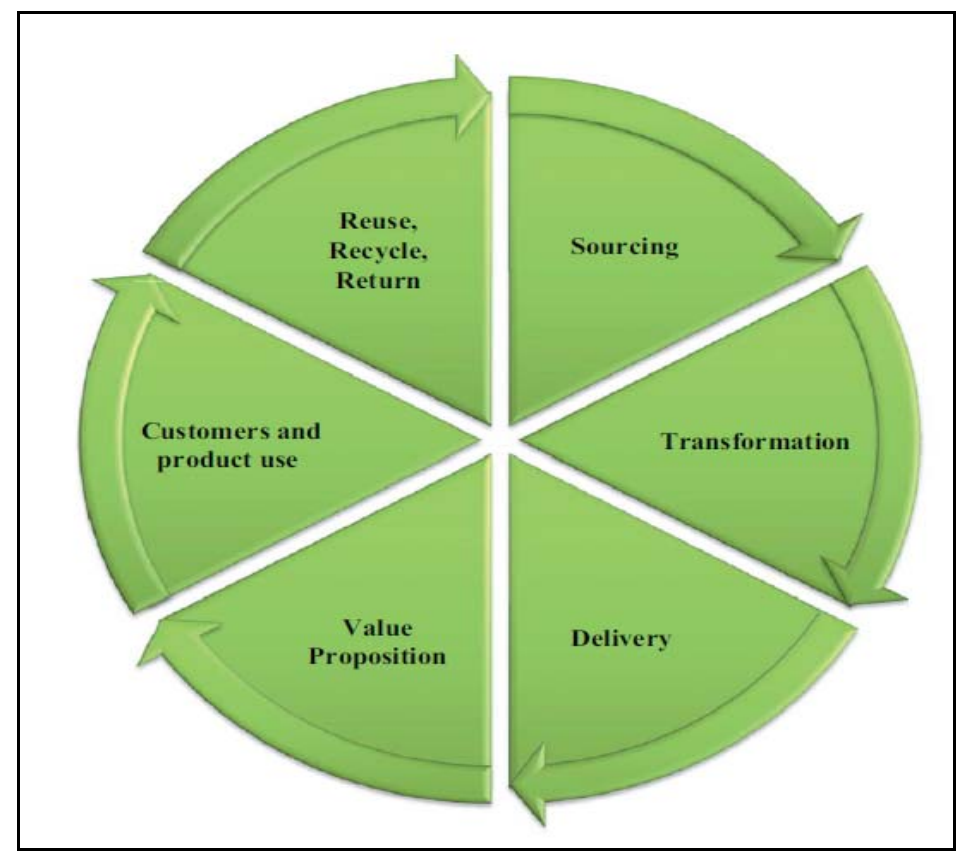

Figure 8. Sustainable Supply Chain Management

Source: (Hassini, Surti, \& Searcy, 2012) 
Apart from visualizing the sustainable supply chain wheel, they identified nine factors in sustainable supply chain as market forces, policy and regulations, science and technology, product development, process capability, sourcing and operations, transport and logistics, marketing and public relations and social issues. They also discussed that how these factors contribute to make the supply chain sustainable.

\section{Methodology}

The research paper uses integrative literature review approach to propose a new framework for SSCM. An integrative literature review is a form of research that reviews, critiques, and synthesizes representative literature on a topic in an integrated way such that new frameworks and perspectives on the topic are generated (Torraco, 2005). A characteristic of a good integrative literature review is that it has a methodology that clearly outlines

- Where the literature was found

- When the search was conducted

- Who conducted the search

- How the literature was found

- What number of articles appeared from each combination of keywords and the final count of included articles, and

- Why some articles were chosen for inclusion over others.

Perhaps the most important distinction of an integrative literature review is that it can be considered, in and of itself, a form of research that can stand alone (Yorks, 2008). Although not empirical per se, an integrative literature review does a systematic and replicable study of the literature. Since integrative literature reviews are distinctive because they systematically trace many (almost all) of the literature on a selected topic back to its roots, authors used it to review all existing frameworks of SSCM before proposing their own framework.

\section{Three Dimensional Framework for SSCM}

Authors propose a three-dimensional framework for SSCM in which the first dimension represented on X-Axis is "Supply Chain" actors, the second dimension on Y-Axis refers to the "Management" while the third dimension on Z-Axis show the "Sustainability". The sequence of actors in supply chain and levels in management and sustainability of the framework are shown in Figure 9 given below. 


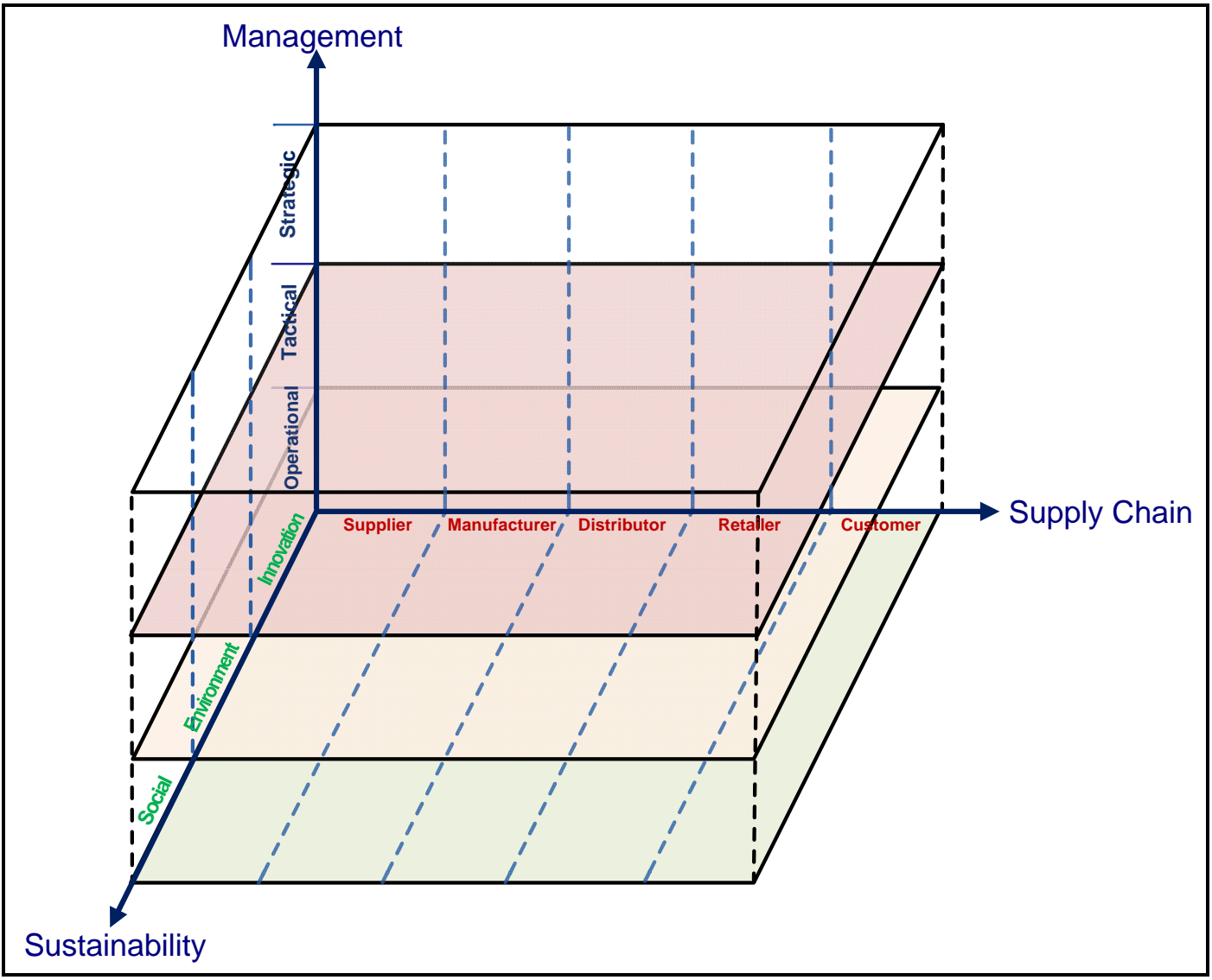

Figure 9. Three-Dimensional Framework for Sustainable Supply Chain Management

\subsection{Dimension 1: Supply Chain}

The literature provides two broad classification of supply chain. One is based on process i.e. procurement, production, distribution and sales, while the other one is based on actors. The actors in a supply chain generally include the supplier, manufacturer, distributor, retailer and the customer. The authors follow "actors" classification in their proposed three-dimensional framework; so that their respective supply chain performance can be measured. These supply chain performance measures are directed on two dimensions, one on "management" to ensure efficiency and effectiveness and the other one on "sustainability" to take care of its stakeholders.

\subsection{Dimension 2: Management}

The management of supply chain is integral and cannot be overlooked by any forward thinking organization. As the literature and practice verifies, the management functions of supply chain are being managed at strategic, tactical and operational levels. The proposed framework by authors represents this on Y-dimension and also put them in three levels as operational, tactical and strategic. A well coordinated and effective application of these three levels on each supply chain actors will ensure efficiency and effectiveness of the supply chain. Strategic level decisions for management of supply chain may include decisions on strategic 
investments in technology and IT, capital investments; location decisions etc. and the performance of SC may be assessed on cost, response time, agility, delivery reliability and efficiency. While, tactical level decisions and measures may include capacity utilization, make cycle time, order entry methods, inventory turnover ratio, total length of the chain, inventory days of supply etc. Similarly, operational level decisions may be based on measures of cost, assets, responsiveness, agility and reliability.

\subsection{Dimension 3: Sustainability}

Authors followed the most acceptable definition of sustainability in literature, which suggests that it must fulfil the objectives on three major dimensions, viz. economic, environmental and social. However, in the proposed three-dimensional framework of SSCM, the right application of all levels of management dimension (Y-Axis) on supply chain actors (X-Axis) i.e. XY dimensions dynamics of the framework addresses the economic responsibility, whereas we consider the sustainability (Z-Axis) as third dimension of the framework. Like three levels of management, authors propose three levels of sustainability dimension, such as innovation, environment and social. And on a conceptual level a parallel can be drawn among the levels of management dimension to the levels of sustainability dimension.

Innovation: This is the operational level of sustainability dimension to all actors of SC. This level is not only integral component to the dimension of sustainability to address environmental and social concerns of the SC actors but also improves economic performance along with all levels of management dimension. In general SC actors embrace innovations which increase profitability (measure on Y-Axis), whereas they need to be innovative to reduce environmental degradation and to become environmentally sustainable. To achieve sustainability, the innovations may take place at organizational level, process level, product level, market level and environmental level. Innovations at organizational level may consider organizational structure and management systems, while process level may include introduction of a new process for making or delivering goods and services. Product level innovations may consist of introduction of new product or a significant qualitative change in an existing product. Environment level innovation may spread across the supply chain, including steps taken by suppliers (reduced packaging), manufacturer (reduction in hazardous substances, energy efficient processes), distributors (reduced packaging, efficient transportation) and customers (reuse and e-waste disposal), whereas innovations at market level may comprise of dealing with competitors and customers.

Environmental: This can be considered as tactical level of the sustainability dimension to address the ecological concerns of SC actors. The organizations moving towards achieving sustainability must include green practices to save environment, which also has impact on social wellbeing in a long run. This entails innovation in existing way of managing SC such as cleaner sources of energy and efficient utilization of using existing processes provide cost benefits along with reducing emission of greenhouse gases. Environmental performance of the SC may be assessed on green manufacturing, green product and packaging along with waste management, recycling, use of alternate sources of energy and compliance of environmental rules and regulations. SC actors should not only fulfill the compliance norms 
of the government but should also innovate to improve the benchmark and standards.

Social: This is the strategic and highest level of sustainability dimension and addresses the issues of stakeholders. The actors in supply chain must be accountable for their actions, which have a negative impact on internal and external customers as well as the society at large. Organizations can increase the trust of the stakeholders by reporting transparently with accountability and promote ethical business practices. Transparency in work culture, providing equal opportunity of employment, compliance with regulations and fair implementation of policies and procedures may contribute to the sustainability of the organization. The contribution to the social justice, upholding of the human rights, discouraging child labour, handling layoffs and worker disputes, and providing relief during catastrophic disasters etc. can be considered as performance measures of social level of the sustainability dimension.

Sustainability in supply chain can be achieved not only by its economic accomplishment but also by successfully addressing the environmental and social issues through innovations. So the various supply chain actors while deciding their SC performance should not only consider efficiency and effectiveness but also their performance on innovation, environment and social through all levels of management. This framework suggests that sustainability as functional dimension (Z-Axis) must complement to the functional management dimension (Y-Axis) on each of the SC actors to make it as SSCM.

\section{Conclusion}

The increasing environmental and social concerns at global, regional, national and local levels are being embraced by the researchers, governments and the business firms with varying degree of commitments. In most part of the world, regional and national governments normally consider it low on priority, least on commitment and dismal on compliance, while business firms consider them non-economic and expensive. However, researchers find these occurrences reasonable to be addressed in managing the businesses and their supply chain. Researchers have not only defined the sustainability but also proposed several frameworks to make their supply chain sustainable.

The authors have used integrative literature review approach to know that how the concept of supply chain have graduated from supply chain management to green supply chain management and then to sustainable supply chain management. Fundamentally all SSCM frameworks use Triple Bottom Line (TBL) perspective given by Elkington (1998) incorporating economic, environmental, and social dimensions. The proposed three-dimensional SSCM by authors suggest that a proper planning (strategic and tactical) and execution (operational) of Management dimension (Y-Axis) on all supply chain actors (X-Axis) will lead to economic efficiency and effectiveness of the SC, which could be rightly termed as SCM. But an effective use of Management dimension on innovation, environment and social i.e. Sustainability dimension (Z-Axis) on all SC actors will make it a SSCM. The functional acts of management and sustainability on actors of supply chain make it three-dimensional SSCM. 
The proposed three-dimensional framework for SSCM will help to conceptualize and design a new paradigm in supply chain. The need is to make the supply chain sustainable; while it makes profit from its operations, it should not damage the environment and exploit the society. When the managers need to think at strategic, tactical and operational levels and delineate the activities that need to be performed at each level to achieve economic performance they also need to do the same for achieving sustainability. This conceptual framework needs empirical validation at the field level.

\section{References}

Ayers, J. (2006). Handbook of Supply Chain Management. Boca Raton, New York: Auerbach Publications.

Barve, A., \& Muduli, K. (2011). Challenges to Environmental Management Practices in Indian Mining Industries. International Conference on Innovation, Management and Service IPEDR. Vol.14. Singapore: IACSIT Press.

Bigliardi, B., \& Dormio, A. (2009). An empirical investigation of innovation determinants in food machinery enterprises. Europian Journal of Innovation Management, 12(2), 223-242. http://dx.doi.org/10.1108/14601060910953988

Carter, C., \& Rogers, D. (2008). A framework of sustainable supply chain management: moving toward new theory. International Journal of Physical Distribution \& Logistics Management, 38(5), 360-387. http://dx.doi.org/10.1108/09600030810882816

Chow, W., Madu, C., Kuei, C., Lu, M., Lin, C., \& Tseng, H. (2006). Supply chain management in the US and Taiwan: An empirical study. Omega, Available online 5 May 2006.

Christmann, P. (2000). Effects of best practices of environmental management on cost advantage: The role of complementary assets. Academy of Management Journal, 43(4), 663-680. http://dx.doi.org/10.2307/1556360

Cooper, R. G. (1999). The Invisible Success Factors in Product Innovation. Journal of Product Innovation Management, 16(2), 115-133. http://dx.doi.org/10.1111/1540-5885.1620115

Darnall, N., Henriques, I., \& Sadorsky, P. (2008). Do environmental management systems improve business performance in an international setting? Journal of International Management, 14, 364-376. http://dx.doi.org/10.1016/j.intman.2007.09.006

Dey, A., LaGuardia, P., \& Srinivasan, M. (2011). Building sustainability in logistics operations: a research agenda. Management Research Review, 34(11), 1237-1259. http://dx.doi.org/10.1108/01409171111178774

Dowlatshahi, S. (2000). Developing a theory of reverse logistics. Interfaces, 30(3), 143-155. http://dx.doi.org/10.1287/inte.30.3.143.11670

Dyllick, T., \& Hockerts, K. (2002). Beyond the business case for corporate sustainability. 
Business Strategy and the Environment, 11(2), 130-141. http://dx.doi.org/10.1002/bse.323

Elkington, J. (1998). Cannibals with Forks: The Triple Bottom Line of the 21st Century. Stoney Creek, CT: New Society Publishers.

Fleischmann, B., \& Meyr, H. (2003). Planning Hierarchy, Modeling and Advanced Planning Systems. In A. de Kok, \& S. Graves, Supply Chain Management: Design, Coordination, Operation, Handbooks in Operations Research and Management Science (pp. 457-523). Amsterdam.

Fleischmann, B., Meyr, H., \& Wagner, M. (2002). Avanced Planning. In H. Stadtler, \& C. Kilger, Supply Chain Management and Advanced Planning - Concepts, Models, Software and Case Studies, (pp. 71-96). Berlin: Springer Verlag. http://dx.doi.org/10.1007/978-3-662-10142-1_5

Flint, D. J., Larsson, E., \& Gammelgaard, B. (2008). Exploring processes for customer value insights, supply chain learning and innovation: An international study. Journal of Business Logistics, 29(1), 257-XI. http://dx.doi.org/10.1002/j.2158-1592.2008.tb00078.x

Forresterr, J. (1961). Industrial Dynamics. Cambridge, MA: MIT Press.

Fortes, J. (2009). Green Supply Chain Management: A Literature Review. Otago Management Graduate Review, 7(1), 51-62.

Fox, M., Chionglo, J., \& Barbuceanu, M. (1993). The Integrated Supply Chain Management System. Working Paper, Enterprise Integration Laboratory, University of Toronto. Retrieved from http://www.ie.utoronto.ca/EIL/public/iscm-intro.ps

Freeman, R. (1984). Strategic Management: A Stakeholder Approach. Boston, MA: Pitman.

Gladwin, T., Kennelly, J., \& Krause, T. (1995). Shifting paradigms for sustainable development: implications for management theory and research. Academy of Management Review, 20(4), 874-907.

Greenhalgh, C., \& Rogers, M. (2010). Innovation, Intellectual Property, and Economic Growth. Princeton, New Jersey: Princeton University Press.

Gupta, V., Abidi, N., Bansal, T., \& Jain, R. K. (2013). Green Supply Chain Management Initiatives by IT Companies in India. The IUP Journal of Operations Management, XII(2), 6-24.

Hassini, E., Surti, C., \& Searcy, C. (2012). A literature review and a case study of sustainable supply chains with a focus on metrics. International Journal of Production Economics, 140(1), 69-82. http://dx.doi.org/10.1016/j.ijpe.2012.01.042

Hervani, A. A., Helms, M., \& Sarkis, J. (2005). Performance measurement for green supply chain management. Benchmarking: An International Journal, 12(4), 330-353. http://dx.doi.org/10.1108/14635770510609015

Jan Stentoft, A., Henning, d. H., \& Balslev, M. K. (2011). Exploring supply chain innovation. 
Logistics Research, 3(1), 3-18. http://dx.doi.org/10.1007/s12159-010-0044-3

Jennings, P., \& Zandbergen, P. (1995). Ecologically sustainable organizations: an institutional approach. Academy of Management Review, 20(4), 1015-52.

Kahn, K. (2001). Product Planning Essentials. Thousand Oaks, CA: Sage Publications Inc.

Kaplan, R., \& Norton, P. (2007). Using the Balanced Scorecard as a Strategic Management System. Harvard Business Review, 85(7/8), 150-161.

Machiba, T. (2009, June). Sustainable Manufacturing and Eco-Innovation : Framework, Practices and Measurement. Retrieved December 15, 2010, from http://www.oecd.org/sti/inno/43423689.pdf

Mann, H., Kumar, U., Kumar, V., \& Mann, I. (2010). Drivers of Sustainable Supply Chain Management. The IUP Journal of Operations Management, Vol. IX(No. 4), 52-63.

Meade, L., Sarkis, J., \& Presley, A. (2007). The theory and practice of reverse logistics. International Journal of Logistics Systems and Management, 3(1), 56-84. http://dx.doi.org/10.1504/IJLSM.2007.012070

Mentzer, J. T., DeWitt, W., Keebler, J. S., Min, S., Nix, N. W., Smith, C. D., \& Zacharia, Z. G. (2001). Defining Supply Chain Management. Journal of Business Logistics, 22(2), 1-25. http://dx.doi.org/10.1002/j.2158-1592.2001.tb00001.x

METI, J., \& OECD. (2010). Analysing national policies and business best practices on eco-innovation. Retrieved from http://www.meti.go.jp/meti_lib/report/2010fy01/E000814.pdf

Modi, S. B. (2006). Role of supply chain capabilities in organizational innovation efforts. Indiana University. Indiana: ProQuest Dissertations and Theses.

Naslund, D., \& Williamson, S. (2010). What is Management in Supply Chain Management? A Critical Review of Definitions, Frameworks and Terminology. Journal of Management Policy and Practice, 11(4), 11-28.

New, S. (1997). The scope of supply chain management research. Supply Chain Management: An International Journal, 2(1), 15-22. http://dx.doi.org/10.1108/13598549710156321

O’Connor, J. (1994). Is sustainable capitalism possible? In Is Capitalism Sustainable? (pp. 152-75). New York: The Guildford Press.

Olhager, J., Perssom, F., Parborg, B., \& Rosén, S. (2002). Supply chain impact at Ericsson from product units to demand-driven supply chains. International Journal of Technology Management, 23(1/2/3), 40-59. http://dx.doi.org/10.1504/IJTM.2002.002997

Pagell, M., \& Wu, Z. (2009). Building a more complete theory of sustinable supply chain management using case studies of 10 exemplers. Journal of Supply Chain Management, 45(2), 37-56. http://dx.doi.org/10.1111/j.1745-493X.2009.03162.x

Prahinski, C., \& Kocabasoglu, C. (2006). Empirical research opportunities in reverse supply chains. Omega, 24(6), 519-32. http://dx.doi.org/10.1016/j.omega.2005.01.003 
Ramudhin, A., Chaabane, A., \& Paquet, M. (2010). Carbon market sensitive sustainable supply chain network design. International Journal of Management Science and Engineering Management, 5(1), 30-38.

Rao, P., \& Holt, D. (2005). Do green supply chains lead to competitiveness and economic performance? International Journal of Operations \& Production Management, 25(9), 898-916. http://dx.doi.org/10.1108/01443570510613956

Rogers, E. M. (1995). Diffusion of Innovations (4th ed.). New York: Glencoe: Free Press.

Santos, B. L., \& Smith, L. S. (2008). RFID in the supply chain: panacea or Pandora's box? Magazine Communications of the ACM, 51(10), 127-131. http://dx.doi.org/10.1145/1400181.1400209

Seuring, S., \& Muller, M. (2008). From a literature review to a conceptual framework for sustainable supply chain management. Journal of Cleaner Production, 16, 1699-1710. http://dx.doi.org/10.1016/j.jclepro.2008.04.020

Singh, N., \& Shah, J. (2001). "Benchmarking Internal supply chain performance: development of a framework”,. The Journal of Supply Chain Management, winter, 37-47.

Soosay, C. A., Hyland, P. W., \& Ferrer, M. (2008). Supply chain collaboration: Capabilities for continuous innovation. Supply Chain Management, 13(2), 160-169. http://dx.doi.org/10.1108/13598540810860994

Spreckley, F. (1981). Social Audit - A Management Tool for Co-operative Working. Leeds, UK: Beechwood College Ltd.

Srivastava, S. (2007). Green Supply-Chain Management: A State-of-the-Art Literature Review. International Journal of Management Reviews, 9(1), 53-80. http://dx.doi.org/10.1111/j.1468-2370.2007.00202.x

Srivastava, S. K., \& Srivastava, R. K. (2006). Managing product returns for reverse logistics. International Journal of Physical Distribution and Logistics Management, 36(7), 524-546. http://dx.doi.org/10.1108/09600030610684962

Starik, M., \& Rands, G. (1995). Weaving an integrated web: multilevel and multisystem perspectives of ecologically sustainable organizations. Academy of Management Review, 20(4), 908-35.

Storer, M., \& Hyland, P. (2009). Dynamic capabilities and innovation in supply chains. Enhancing the innovation environment: Proceedings of the 10th International CINet Conference. Brisbane.

Torraco, R. J. (2005). Writing integrative literature reviews: Guidelines and examples . Human Resource Development Review, 4, 356-367. http://dx.doi.org/10.1177/1534484305278283

Yorks, L. (2008). What we know, what we don't know, what we need to know-Integrative literature reviews are research. Human Resource Development Review, 7, 139-141. 


\section{Macrothink}

Journal of Management Research

ISSN 1941-899X

2013, Vol. 5, No. 4

http://dx.doi.org/10.1177/1534484308316395

Zhu, Q., \& Sarkis, J. (2004). Relationships between operational practices and performance among early adopters of green supply chain management practices in Chinese manufacturing enterprises. Journal of Operations Management, 22(3), 265-289. http://dx.doi.org/10.1016/j.jom.2004.01.005

Zhu, Q., Sarkis, J., \& Lai, K. (2007). Green supply chain management: pressures, practices and performance within the Chinese automobile industry. Journal of Cleaner Production, 15(11/12), 1041-1052. http://dx.doi.org/10.1016/j.jclepro.2006.05.021 